Acompañaron al presidente del CICR, en Polonia, los señores: Jean Pictet, vicepresidente del CICR, Jacques Moreillon, director del Departamento de Doctrina y Derecho, Melchior Borsinger, delegado general para Europa y Norteamérica, Alain Modoux, jefe de la División Prensa e Información y otros colaboradores del CICR en Ginebra.

\title{
Fallecimiento del magistrado, señor Paul Carry, miembro honorario del CICR
}

El magistrado, señor Paul Carry, miembro honorario del Comité Internacional de la Cruz Roja, falleció, en Ginebra, el 30 de marzo, después de una breve enfermedad.

Nacido en Roma el año 1892, el señor Carry realizó sus estudios en la Facultad de Derecho de la Universidad de Ginebra, donde obtuvo su licencia en 1913 y su doctorado en 1926. Abogado, profesor adjunto, y luego profesor ordinario de Derecho Comercial en la Universidad de Ginebra, y decano de la Facultad de Derecho, el magistrado señor Carry publicó trabajos de Derecho y numerosos estudios en revistas jurídicas. Varias universidades, en Suiza y en el extranjero, le confirieron el título de doctor honoris causa.

Durante varios años fue miembro del Gran Consejo de Ginebra, y del Consejo Municipal; presidió el Tribunal Supremo de 1942 a 1944, y, en las fuerzas armadas suizas, con el grado de coronel, fue miembro y luego presidente del Tribunal Supremo Militar. Ejerció funciones de juez especial en el Tribunal Internacional de La Haya.

El profesor Carry fue nombrado miembro del Comité Internacional de la Cruz Roja el 23 de diciembre de 1946. Colaboró en la obra jurídica del CICR y en el desarrollo del derecho internacional humanitario. Participó activamente, como delegado de la Institución, en los trabajos de la XVII ${ }^{a}$ Conferencia Internacional de la Cruz Roja, celebrada en Estocolmo el año 1949 y en los de la Conferencia Diplomática de Ginebra, que, desde abril hasta agosto de 1949, elaboró los Convenios de Ginebra de 1949 para la protección de las víctimas de la guerra. Colaboró muy activamente con el CICR en las negociaciones referentes a la aplicación del Artículo 16 del Tratado de Paz con el Japón y realizó, en esa ocasión, varias misiones en distintos países. 
En 1959, el profesor Carry no aceptó ser reelegido miembro del Comité Internacional de la Cruz Roja, pues su estado de salud y sus ocupaciones profesionales le impedían colaborar en la Institución con la misma entrega que en el pasado. El Comité Internacional se inclinó ante esta decisión, $y$, reconociendo los servicios prestados a la obra de la Cruz Roja, le nombró en su sesión del 8 de enero de 1959, miembro honorario. Como tal, el profesor Carry fue consultado con frecuencia y su parecer tenía mucha autoridad.

El Comité Internacional se ha enterado con mucho pesar de su fallecimiento y presenta a su familia su sincero pésame.

\section{Alta distinción de la Cruz Roja Sueca al señor Gallopin}

El señor Roger Gallopin, ex presidente del Consejo Ejecutivo del CICR, recibió la Medalla Real de oro de la Cruz Roja Sueca, la más alta distinción que confiere esa Sociedad.

El presidente de la Cruz Roja Sueca, señor Matts Bergon Larsson, escribe al señor Gallopin, en la carta en que le anuncia la condecoración: " Su personalidad y su posición le han permitido ejercer una extraordinaria influencia, durante muchos años, en nuestro movimiento y en diversos ámbitos de la actividad de la Cruz Roja... Se le confiere, ahora, nuestra más alta distinción como agradecimiento por sus notables contribuciones a la actividad humanitaria y con la esperanza de verlo aún participar, en la dirección del movimiento de la Cruz Roja ». 